\title{
Enantioselective Synthesis of (+)-Cephalostatin 1
}

\section{Citation}

Fortner, Kevin, Darryl Kato, Yoshiki Tanaka, Matthew David Shair. 2010. Enantioselective

Synthesis of (+)-Cephalostatin 1. Journal of the American Chemical Society 132(1): 275-280.

\section{Published Version}

doi:10.1021/ja906996c

\section{Permanent link}

http://nrs.harvard.edu/urn-3:HUL.InstRepos:7982718

\section{Terms of Use}

This article was downloaded from Harvard University's DASH repository, and is made available under the terms and conditions applicable to Open Access Policy Articles, as set forth at http:// nrs.harvard.edu/urn-3:HUL.InstRepos:dash.current.terms-of-use\#OAP

\section{Share Your Story}

The Harvard community has made this article openly available.

Please share how this access benefits you. Submit a story.

\section{Accessibility}




\title{
Enantioselective Synthesis of Cephalostatin 1
}

\author{
Kevin C. Fortner,${ }^{\dagger}$ Darryl Kato,${ }^{\ddagger}$ Yoshiki Tanaka, ${ }^{\S}$ and Matthew D. Shair ${ }^{* \dagger}$ \\ Department of Chemistry and Chemical Biology, Harvard University, 12 Oxford Street, Cambridge,
} MA 02138

shair@chemistry.harvard.edu

RECEIVED DATE (to be automatically inserted after your manuscript is accepted if required according to the journal that you are submitting your paper to)

\begin{abstract}
This manuscript describes an enantioselective synthesis of cephalostatin 1. Key steps of this synthesis are a unique methyl group selective allylic oxidation, directed $\mathrm{C}-\mathrm{H}$ hydroxylation of a sterol at $\mathrm{C} 12, \mathrm{Au}(\mathrm{I})$-catalyzed 5-endo-dig cyclization and a kinetic spiroketalization.
\end{abstract}

KEYWORDS natural product, total synthesis, antiproliferative, cephalostatin

\section{Introduction}

An important property of modern anti-cancer therapeutics is the selective killing of cancer cells over normal cells. One approach to achieve selectivity is "synthetic lethality,"1 involving combination of a mutation, only present in cancer cells, and a small molecule, resulting in selective cell killing of the cells bearing the mutation. Since many genetic mutations have been identified in tumor cells, a challenge is to discover small molecules that selectively target cells harboring these mutations.

We have become interested in the therapeutic potential and cellular target of cephalostatin 1 (1), a natural product that may be synthetic lethal with the $p 16$ tumor suppressor gene. In a bioinformatics comparison of the cytotoxicity profiles of $\sim 43,000$ small molecules with cell lines bearing altered $p 16,1$ 
emerged as the compound with the highest correlation, suggesting that it may be selectively cytotoxic to cells with altered $p 16 .^{2}$ The $p 16$ gene encodes cyclin-dependent kinase inhibitor 2A (CDKN2A or Ink4a), a tumor suppressor protein that blocks cell proliferation by binding to and inhibiting the kinase activity of cyclin-dependent kinase 4 (CDK4) and cyclin-dependent kinase 6 (CDK6). ${ }^{2}$ In cells, both CDK4 and CDK6 each form active complexes with cyclin D that phosphorylate Rb (the retinoblastoma protein), allowing progression through the G1-S phase of the cell cycle. If CDKN2A is inactive due to a mutation or lack of expression, tumor cells can progress uncontrollably through the G1-S phase of the cell cycle. ${ }^{3}$ Since $p 16$ is among the most frequently mutated genes in human tumor cells, $\mathbf{1}$ may be a uniquely selective anti-cancer therapeutic, and elucidation of its unknown cellular target may reveal new ways to achieve synthetic lethality with small molecules.

Cephalostatin 1 was first reported in 1988 as a potent growth inhibitory marine natural product. ${ }^{4}$ The average $\mathrm{GI}_{50}$ of 1 against the NCI-60, a collection of 60 human cancer cell lines, is $1.8 \mathrm{nM} .^{5}$ Three other molecules, ritterazine B (2), ${ }^{6}$ OSW $-1(3)^{7}$ and schweinfurthin A (4) ${ }^{8}$ have cytotoxicity patterns resembling 1, suggesting that all three compounds share similar mechanisms. ${ }^{9}$ The cellular target and mechanism of $\mathbf{1}$ (or 2-4) has not been elucidated, although an increasing amount of research is being focused on these issues. ${ }^{10}$

The unusually large and complex structure of $\mathbf{1}$ has been the target of many synthesis studies, with one synthesis reported by Fuchs. ${ }^{11}$ Due to the small quantities of $\mathbf{1}$ available from natural sources, only through synthesis will sufficient amounts of $\mathbf{1}$ (and analogs) be available to address questions surrounding its potential synthetic lethality with $p 16$, elucidation of its cellular target and mechanism, and determination of its efficacy in vivo. This manuscript reports our synthesis of 1 (Figure 1), enabling us to answer the questions posed above surrounding its biological activity. 


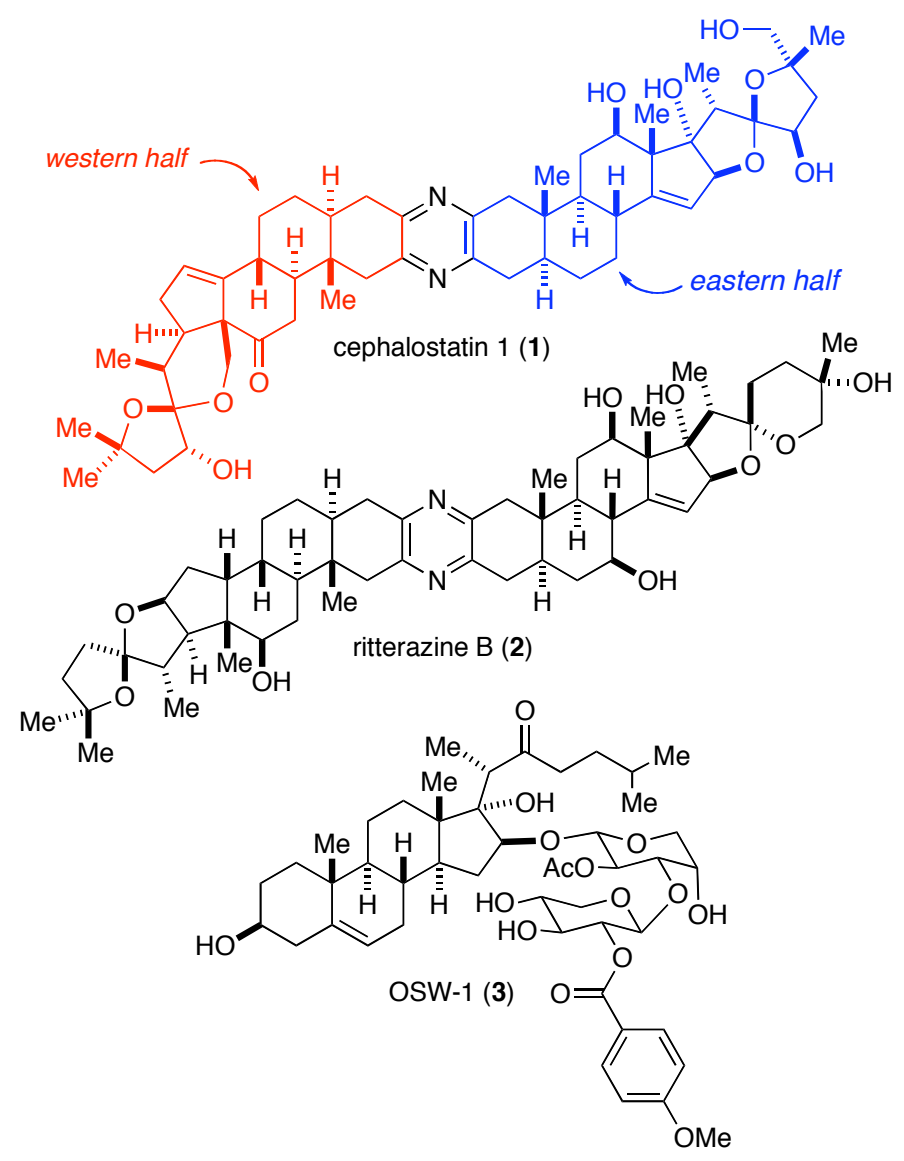

Figure 1. Cephalostatin 1, ritterazine B, OSW-1. Three antiproliferative natural products with similar cytotoxicity patterns.

\section{Synthesis of the western half of cephalostatin $1(5)$.}

Our synthesis plan involved construction of the eastern and western portions of $\mathbf{1}$, followed by unsymmetrical pyrazine formation following the reactions developed by Heathcock ${ }^{12}$ and Fuchs. ${ }^{11 \mathrm{a}, 13}$ The C22 spiroketal of 5 (Scheme 1) is in a thermodynamically favorable configuration, meaning that its stereochemistry can be established by acid-catalyzed equilibration. ${ }^{14}$ Hecogenin acetate (6), an inexpensive plant-derived steroid that is available in kilogram quantities, ${ }^{15}$ is used as the starting material for our synthesis of the western half since it has handles for most of the functionality of $\mathbf{5}$, especially oxygenation at C12. Compound $\mathbf{6}$ was also used by others for their synthesis studies on 1. With 6 as a starting point for synthesis of $\mathbf{5}$, we need to rearrange the spiroketal, oxidize C23, deoxygenate $\mathrm{C} 16$, install a C14-C15 olefin, and most challenging, oxidize the unactivated C18 angular methyl group (see Scheme 1). Our plan was to generate lumihecogenin acetate (7) by photolysis of $\mathbf{6}$, a 
reaction first described by Bladon. ${ }^{16}$ Selective oxidation of C18 of 7 to generate 8 followed by Prins cyclization would deliver $\mathbf{9}$. Compound $\mathbf{9}$ would then be converted to $\mathbf{5}$. We recognized that $\mathbf{7}$ is the only intermediate in our synthesis in which C18 is activated (allylic), and therefore we focused on methods to selectively oxidize the allylic methyl group. This is a significant challenge since the olefin of 7 is tetrasubstituted and there are four other allylic hydrogens (see blue H's), two methines and one methylene. We require an oxidation that is selective for the $\mathrm{C} 18$ methyl group and tolerant of highly hindered double bonds, boundary conditions that exclude many of the known allylic oxidation reactions.

Scheme 1. Synthesis plan for 5 requiring a C18 methyl group-selective allylic oxidation of 7.

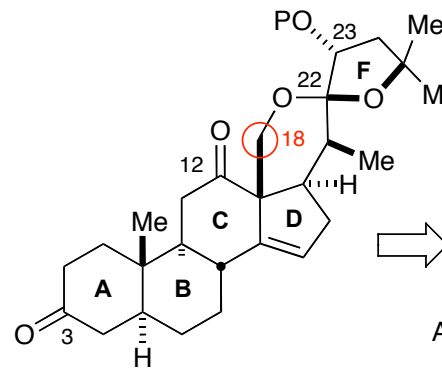

(5)-western half

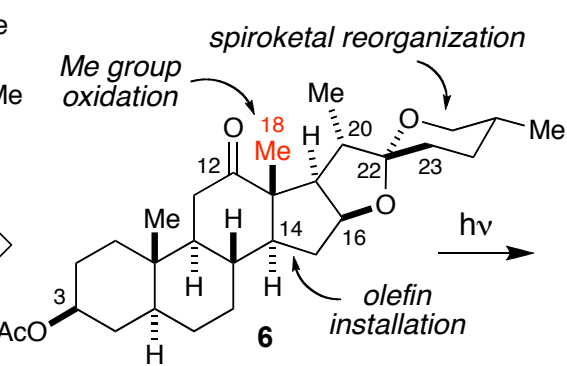

hecogenin acetate

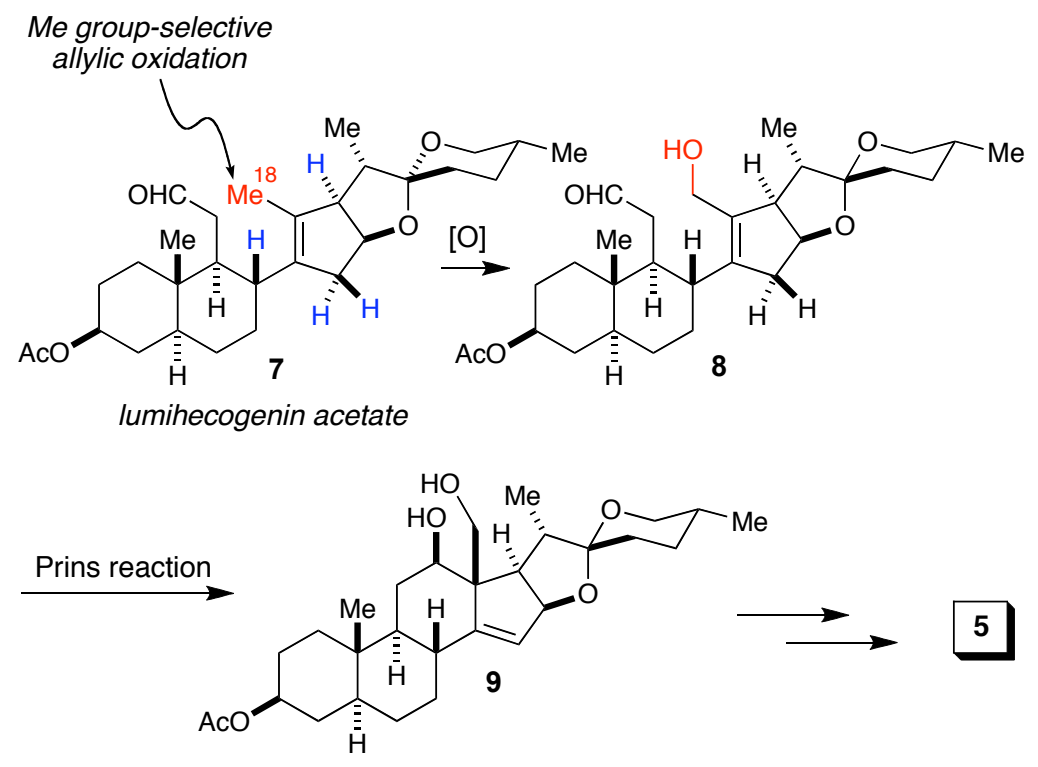

The synthesis of 5 begins with the known conversion of 6 to 7 (Scheme 2). ${ }^{16}$ Attempts to perform allylic oxidation of C18 on either aldehyde 7 or the protected alcohol at C18 were unsuccessful. As 
expected, $\mathrm{SeO}_{2}$ led to hydroxylation of the $\mathrm{C} 15$ methylene. Radical halogenations were poorly regioselective and the hindered double bond was inert to transition metal-catalyzed allylic oxidation reactions.

Scheme 2. Selective C18 methyl group-selective allylic oxidation involving ene reaction, [2,3]sigmatropic rearrangement, and oxidation ${ }^{a}$

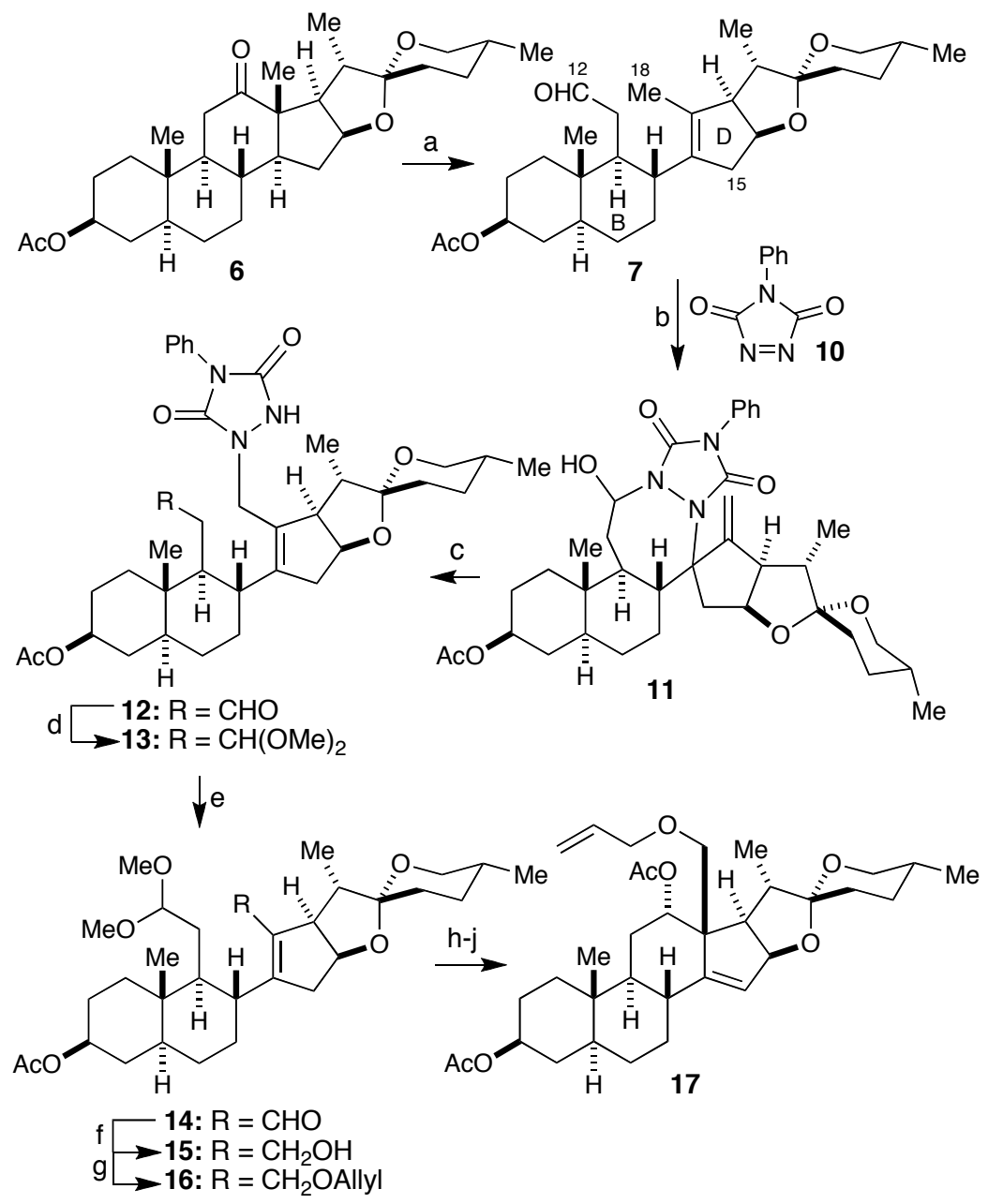

${ }^{a}$ Conditions: (a) hv, 1,4-dioxane, $25{ }^{\circ} \mathrm{C}$; (b) 4-phenyl-1,2,4-triazoline-3,5-dione, dichloroethane, 25 ${ }^{\circ} \mathrm{C}$, 61\% 2 steps; (c) $\mathrm{NaOAc}, \mathrm{DMF}, 100{ }^{\circ} \mathrm{C}$, 69\%; (d) $\mathrm{CH}(\mathrm{OMe})_{3}$, $\mathrm{TsOH} \bullet \mathrm{H}_{2} \mathrm{O}, \mathrm{MeOH}, 25{ }^{\circ} \mathrm{C}$; (e) $\mathrm{PhI}(\mathrm{OAc})_{2}, \mathrm{MeCN} / \mathrm{H}_{2} \mathrm{O}, 0{ }^{\circ} \mathrm{C}$, 64\% 2 steps; (f) $\mathrm{NaBH}_{4}, \mathrm{MeOH}, 0{ }^{\circ} \mathrm{C}, 88 \%$; (g) NaH, DMF, $0{ }^{\circ} \mathrm{C}$; allyl bromide, $25^{\circ} \mathrm{C}$, 93\%; (h) PPTS, acetone, $25^{\circ} \mathrm{C}$; (i) $\mathrm{BF}_{3} \cdot \mathrm{OEt}_{2}, \mathrm{PhMe}^{\circ}{ }^{\circ} \mathrm{C}, 61 \% 2$ steps; (j) $\mathrm{Ac}_{2} \mathrm{O}$, pyr., DMAP, $25^{\circ} \mathrm{C}$.

Ultimately, an unusual allylic oxidation of C18 was achieved. It was discovered that treatment of 7 with 4-phenyl-1,2,4-triazoline-3,5-dione (PTAD, 10), a potent eneophile, lead directly to $\mathbf{1 1}$ achieving 
selective functionalization of the C18 methyl group. Selective activation of the C18 methyl, via an apparent ene reaction, combined with formation of a seven-membered aminal. This transformation may in fact be directed by the $\mathrm{C} 12$ aldehyde since the corresponding $\mathrm{C} 12$ dimethyl acetal reacted to form a PTAD adduct with abstraction of a $\mathrm{C} 15$ proton. One explanation for the selective activation of C18 in this reaction involves initial formation of a zwitterionic adduct (18) between PTAD (10) and aldehyde 7 (Scheme 3). This species could participate in an intramolecular aza-Prins reaction via intermediate 19. Close proximity between the $\mathrm{C} 12$ alkoxide and the C18 methyl group in $\mathbf{1 9}$ could explain the selective proton abstraction at $\mathrm{C} 18$. Alternatively, PTAD could add to the $\mathrm{C} 12$ aldehyde via its carbonyl and engage in an ene reaction, although inspection of molecular models appears to preclude this mechanism due to lack of required orbital overlap. Finally, an ene reaction may occur between $\mathbf{1 0}$ and $\mathbf{7}$ followed by hemiaminal formation.

Treatment of 11 with sodium acetate induced opening of the hemiaminal followed by apparent $[2,3]$ sigmatropic rearrangement, affording allylic $\mathrm{N}-\mathrm{Ph}$ urazole 12 (Scheme 3). Protection of the $\mathrm{C} 12$ aldehyde as its dimethyl acetal was followed by oxygenation of $\mathrm{C} 18$ by treatment of $\mathbf{1 3}$ with $\mathrm{PhI}(\mathrm{OAc})_{2}$, affording aldehyde 14. In this reaction, the $\mathrm{N}-\mathrm{N}$ bond is oxidized to $\mathrm{N}=\mathrm{N}$. Tautomerization, addition of water, and release of the urazole affords 14. Allylation of the primary hydroxyl group, followed by acid catalyzed acetal hydrolysis set the stage for C-ring closure which was accomplished by treatment with $\mathrm{BF}_{3} \cdot \mathrm{OEt}_{2}$ (Scheme 2). Finally, acetylation of the secondary alcohol provided $\mathbf{1 7}$. 
Scheme 3. Proposed mechanism of the selective aza-Prins reaction, [2,3]-sigmatropic rearrangement, and urazole oxidative hydrolysis

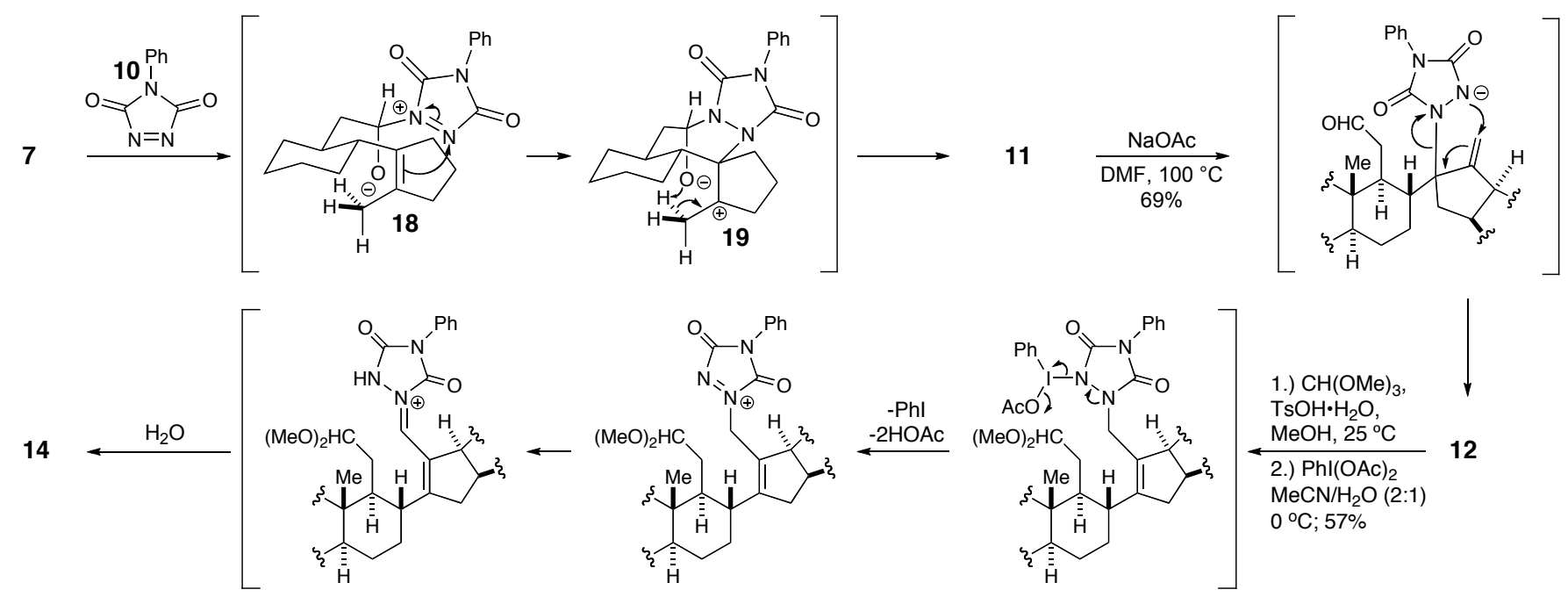

Starting with compound 17, allyl group-selective oxidative olefin cleavage, aldehyde reduction and protection of the resulting primary hydroxyl afforded 20 (Scheme 4). Next, the atoms comprising the spiroketal were removed starting with application of a modified Marker degradation. ${ }^{17}$ Treatment of 20 with trifluoroacetyl trifluoromethanesulfonate (TFAT) opened the F-ring, giving E-ring dihydrofuran 21. Oxidative cleavage of the cyclic enol ether provided the corresponding ketoester, which was subjected to DBU-promoted elimination. The product, dienone 22 underwent 1,4 reduction under platinum-catalyzed hydrosilylation conditions, affording the saturated methyl ketone $\mathbf{2 3}$ as a 4:1 mixture of $\beta / \alpha$-methyl ketone stereoisomers. After removal of the TBDPS ether, and separation of the diastereomers, the undesired C17 $\alpha$-methyl ketone was equilibrated in favor of the $\beta$-diastereomer. Oxidation of the C23 primary hydroxyl preceded an intramolecular aldol reaction to afford enal $\mathbf{2 6 .}$

Scheme 4. Conversion of 17 to cephalostatin 1 western half $(\mathbf{5})^{a}$ 


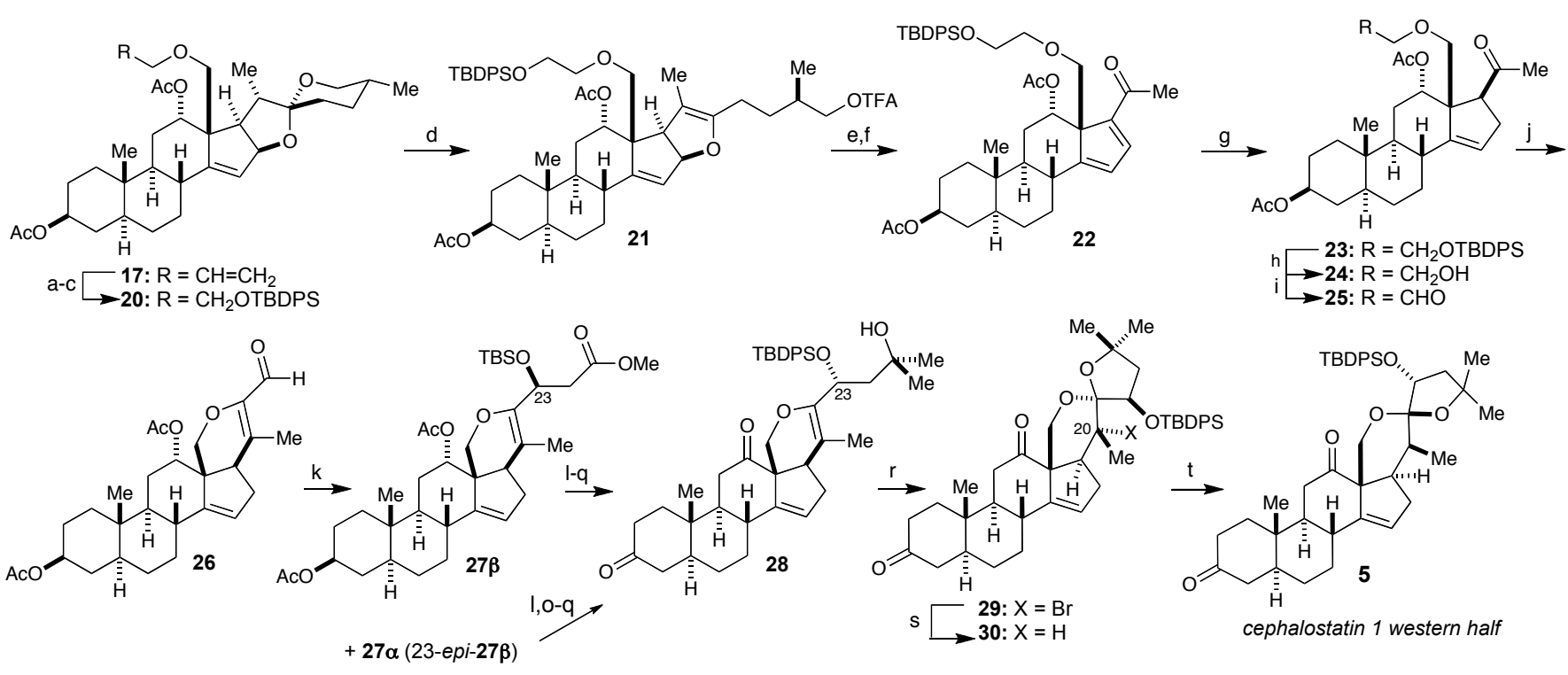

${ }^{a}$ Conditions: (a) $\mathrm{OsO}_{4}, \mathrm{NaIO}_{4}, 2$,6-lutidine, 1,4-dioxane $/ \mathrm{H}_{2} \mathrm{O}, 25{ }^{\circ} \mathrm{C}$; (b) $\mathrm{NaBH}(\mathrm{OAc})_{3}, \mathrm{PhH} / \mathrm{AcOH}, 0$ ${ }^{\circ} \mathrm{C}$; (c) TBDPSCl, Im., DMAP, $\mathrm{CH}_{2} \mathrm{Cl}_{2}, 25{ }^{\circ} \mathrm{C}, 74 \% \quad 4$ steps; (d) trifluoroacetyl trifluoromethanesulfonate, 2,6-tert-butyl-4-methyl-pyridine, $\mathrm{CH}_{2} \mathrm{Cl}_{2},-78{ }^{\circ} \mathrm{C}$, then $\mathrm{PPTS}, \mathrm{CH}_{2} \mathrm{Cl}_{2}, 40{ }^{\circ} \mathrm{C}$; (e) PCC, $\mathrm{CH}_{2} \mathrm{Cl}_{2}, 25{ }^{\circ} \mathrm{C}$; (f) DBU, $\mathrm{CH}_{2} \mathrm{Cl}_{2}, 43 \% 3$ steps; (g) $\left(\mathrm{HMe}_{2} \mathrm{Si}\right)_{2} \mathrm{O}, \mathrm{H}_{2} \mathrm{PtCl}_{6}, \mathrm{PhMe}, 25^{\circ} \mathrm{C}$; (h) TBAF, AcOH, THF, $25^{\circ} \mathrm{C}, 51 \% 2$ steps; (i) DMSO, $i$-PrNEt $2, \mathrm{SO}_{3} \bullet p y r, \mathrm{CH}_{2} \mathrm{Cl}_{2}, 25{ }^{\circ} \mathrm{C}$; (j) piperidine, $\mathrm{AcOH}, 25{ }^{\circ} \mathrm{C}, 75 \% 2$ steps; (k) 1-methoxy-1- tert-butyldimethylsilyloxyethene, $\mathrm{LiClO}_{4}, \mathrm{CH}_{2} \mathrm{Cl}_{2}, \mathbf{2 7 \beta}$ : 51\%, 27 $\alpha$ : 18\%; (1) TBAF, THF, $25^{\circ} \mathrm{C}, 100 \%$; (m) $\mathrm{Ph}_{3} \mathrm{P}$, DIAD, chloroacetic acid, THF, $25^{\circ} \mathrm{C}, 69 \%$; (n) HDTC, 2,6-lutidine, AcOH, $25{ }^{\circ} \mathrm{C}, 80 \%$; (o) TBDPSCl, Im., DMAP, $\mathrm{CH}_{2} \mathrm{Cl}_{2}, 25{ }^{\circ} \mathrm{C}$, 93\%; (p) $\mathrm{MeMgBr}, \mathrm{Et}_{2} \mathrm{O}, 25^{\circ} \mathrm{C}$; (q) TPAP, NMO, $\mathrm{CH}_{2} \mathrm{Cl}_{2}, 25^{\circ} \mathrm{C}, 69 \% 2$ steps; (r) PhSeBr, pyridine, $\mathrm{CH}_{2} \mathrm{Cl}_{2},-78$ ${ }^{\circ} \mathrm{C}$ to $0{ }^{\circ} \mathrm{C}, 92 \%$; (s) AIBN, $\mathrm{Bu}_{3} \mathrm{SnH}$, toluene, $100{ }^{\circ} \mathrm{C}, 100 \%$; (t) CSA, DCE, $83{ }^{\circ} \mathrm{C}, 78 \%$.

Installation of the C24-C25 fragment of the incipient F-ring was accomplished by way of a Mukaiyama aldol reaction. Thus, treatment of aldehyde $\mathbf{2 6}$ with the enolsilane of methyl acetate in the presence of lithium perchlorate delivered a 3:1 mixture of diastereomers favoring the undesired 23- $(S)-$ stereoisomer (27 $\beta$ ). Unfortunately, extensive efforts to override the substrate's inherent facial selectivity for aldol addition were met with failure. Attempts at Mukaiyama aldol addition with other catalysts, including chiral catalysts, afforded product mixtures favoring 23-(S)-configured products. Likewise, chiral auxiliary-based acetate equivalents reacted to give predominantly adducts with the undesired 23-(S) stereochemistry. Removal of the TBS group from 27 $\beta$, Mitsunobu reaction with chloroacetic acid, hydrolysis of the chloroacetate, silylation of the C23 secondary carbinol and addition of excess MeMgBr afforded 28 after oxidation with TPAP/NMO.

Since the spiroketal of $\mathbf{5}$ is known to be under thermodynamic control, we expected mild acid treatment of $\mathbf{2 8}$ to furnish the F-ring while establishing the desired $(S)$-stereochemistry at C20. 
However, in the presence of camphorsulfonic acid, 28 cyclized to give a spiroketal with 20-(R) stereochemistry. Surprisingly, the observed product results from protonation of the more hindered concave face of the dihydropyran E-ring. This result is in contrast to a similar reaction reported by Fuchs in which protonation of a compound closely related to $\mathbf{2 8}$ (except that the C14-C15 double bond was saturated) afforded the desired C20-(S) stereochemistry. ${ }^{14}$

This outcome was corrected by a two-step bromoetherification/reductive debromination sequence. Bromoetherification of $\mathbf{2 8}$ with phenylselenyl bromide afforded 29. Reductive dehalogenation of 29 delivered $\mathbf{3 0}$ as a single diastereomer with hydrogen atom addition occurring from the convex face. To complete the preparation of the cephalostatin western half $\mathbf{5}, \mathrm{C} 22$ was epimerized by treatment of $\mathbf{3 0}$ with camphorsulfonic acid in refluxing dichloroethane.

\section{Synthesis of the cephalostatin 1 eastern half (31).}

The $\mathrm{E}$ and $\mathrm{F}$ rings of the eastern half of cephalostatin 1 consist of a 5,5-spiroketal in a thermodynamically unfavorable configuration at C22 requiring kinetic control for its formation (Scheme $5,31)$. The spiroketal in the natural $C 22-(S)$ configuration exhibits a single anomeric effect, while the unnatural C22- $(R)$ configuration permits additional stabilization due to a second anomeric effect. To form the 5,5-spiroketal, we planned to induce cyclopropane opening on $\mathbf{3 2}$ concurrent with irreversible attack by the $\mathrm{C} 25$ hydroxyl group on the less hindered $\beta$-face of the incipient oxonium ion, which would simultaneously give rise to the desired configurations of both the C22 spiroketal and the C21 methyl group. Rather than starting with hecogenin acetate (6) to make use of its $\mathrm{C} 12$ oxygenation as for the western half of $\mathbf{1}$, we thought it more expedient to hydroxylate the $\mathrm{C} 12$ position of the steroid transandrosterone (34) by a remote $\mathrm{C}-\mathrm{H}$ oxidation process (see Scheme 5,34 ). To increase convergency of the synthesis of $\mathbf{3 2}$, the remote oxidation of $\mathbf{3 4}$ would be followed by Sonogashira cross coupling with alkyne 33, which comprises seven of the eight carbons of the E,F-rings spiroketal. 
Scheme 5. Synthesis plan for 31 requiring a remote oxidation of $\mathbf{3 4}$ and Sonogashira coupling with 33

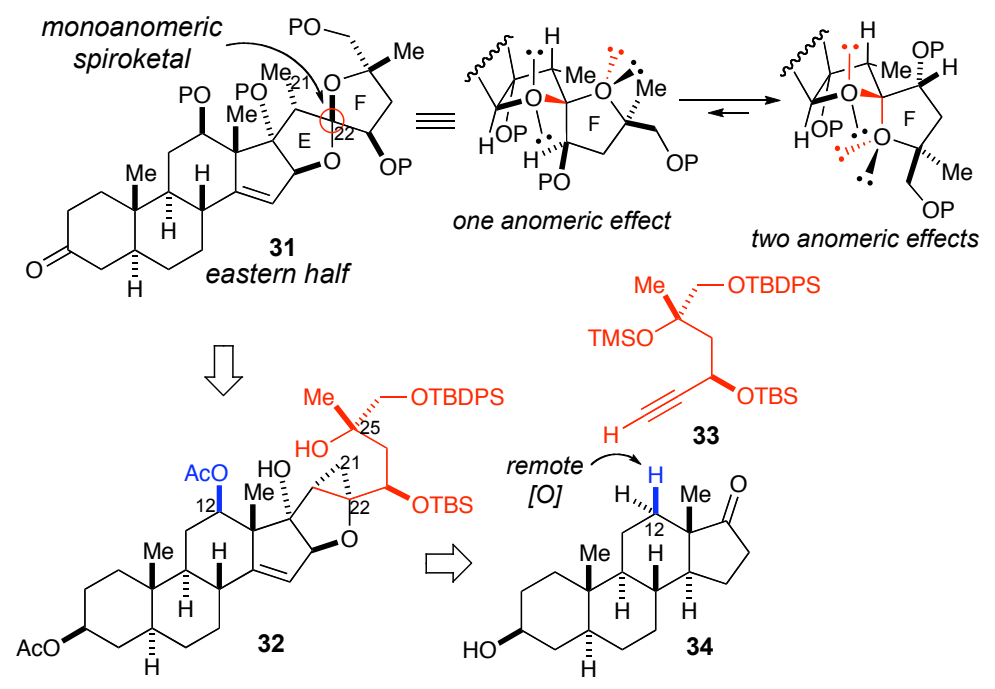

Our synthesis of alkyne 33 began with the known diol 35 (two steps from 3-methyl-3-buten-1-ol, 89\% yield, $96 \%$ ee). ${ }^{18}$ We protected the primary hydroxyl as a TBDPS ether, removed the PMP group by CAN oxidation, and protected both hydroxyl groups of the resulting 1,3-diol as TMS ethers to afford 37 in $80 \%$ yield over three steps (Scheme 6). The Swern reagent chemoselectively converted the TMS ether of the primary carbinol directly into aldehyde 38. Carreira alkynylation ${ }^{19}$ with ethynyltrimethylsilane favored the desired (4R)-propargyl alcohol by 32:1 and provided it in 57\% yield from 37. The secondary carbinol was protected as a TBS ether to deliver $\mathbf{3 9}$ and the alkynyl TMS was removed with $\mathrm{AgNO}_{3}$ and 2,6-lutidine, ${ }^{20}$ affording alkyne 33.

Scheme 6. Synthesis of alkyne 33 from known diol $\mathbf{3 5}^{a}$

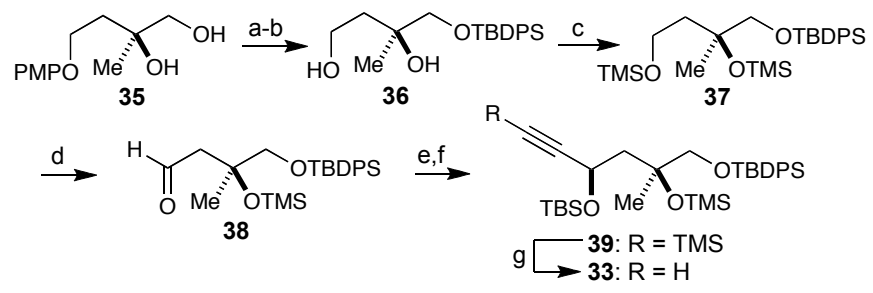

${ }^{a}$ Conditions: (a) TBDPSCl, imidazole, DMF; (b) $\mathrm{CAN}, \mathrm{CH}_{3} \mathrm{CN}, \mathrm{H}_{2} \mathrm{O}, 0{ }^{\circ} \mathrm{C}$; (c) $\mathrm{TMSCl}$, imidazole, DMF, 80\% 3 steps; (d) oxalyl chloride, DMSO, $\mathrm{Et}_{3} \mathrm{~N}, \mathrm{CH}_{2} \mathrm{Cl}_{2},-78{ }^{\circ} \mathrm{C}$; (e) $\mathrm{Zn}(\mathrm{OTf})_{2}$, (+)-Nmethylephedrine, $\mathrm{Et}_{3} \mathrm{~N}$, ethynyltrimethylsilane, toluene, $40{ }^{\circ} \mathrm{C}, 57 \% 2$ steps; (f) $\mathrm{TBSCl}$, imidazole, DMAP, $\mathrm{CH}_{2} \mathrm{Cl}_{2}$; (g) $\mathrm{AgNO}_{3}$, THF, $\mathrm{H}_{2} \mathrm{O}, \mathrm{EtOH}, 2$,6-lutidine, $93 \% 2$ steps. 
Our synthesis of the steroid-derived Sonogashira coupling partner began with the commercially available steroid trans-androsterone 34 (Scheme 7). Utilizing the procedure of Schönecker for the hydroxylation of unactivated $\mathrm{C}-\mathrm{H}$ bonds, ${ }^{21}$ we treated the steroid with 2-(aminomethyl)pyridine and catalytic TsOH to form imine 40 in $89 \%$ yield. Treatment of 40 with $\mathrm{Cu}(\mathrm{OTf})_{2}$, benzoin, and $\mathrm{Et}_{3} \mathrm{~N}$ in acetone to generate $\mathrm{Cu}(\mathrm{I})$, followed by the addition of molecular oxygen resulted in hydroxylation at the unactivated C12 position. Hydrolytic workup provided diol 41 as a single diastereomer in $25 \%$ yield. Acetylation with $\mathrm{Ac}_{2} \mathrm{O}$ /pyridine and treatment with $\mathrm{PhN}(\mathrm{Tf})_{2} / \mathrm{KHMDS}$ led to vinyl triflate 43 in $88 \%$ yield.

Scheme 7. Synthesis of vinyl triflate $\mathbf{4 3}$ from commercially-available trans-androsterone $\mathbf{3 4}$ by remote oxidation at $\mathrm{C} 12^{a}$
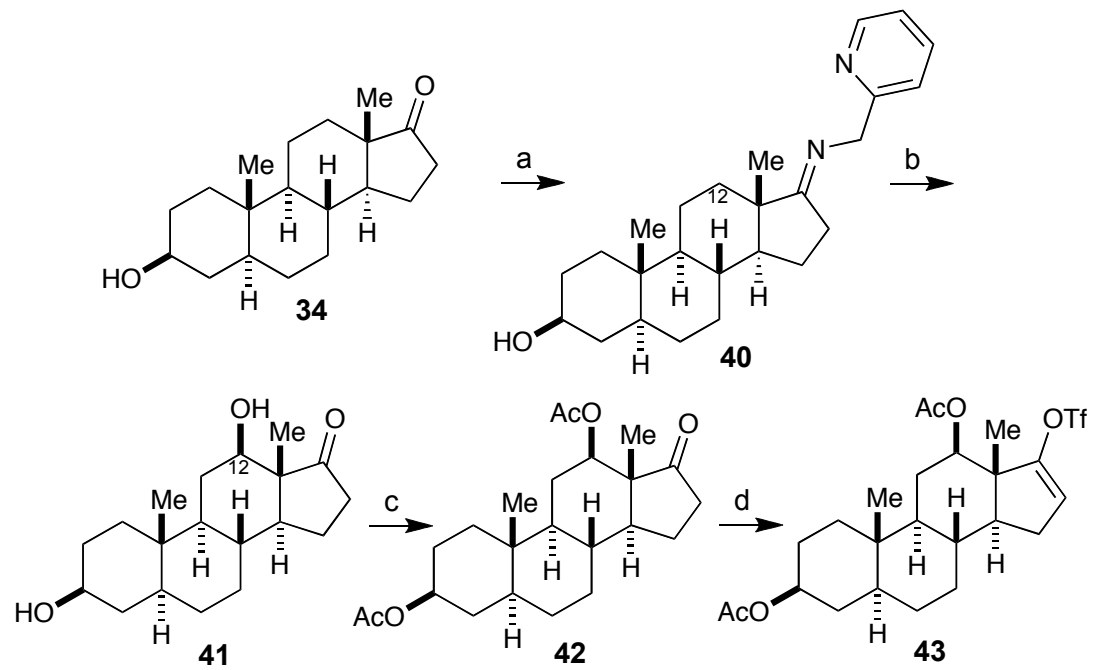

${ }^{a}$ Conditions: (a) 2-aminomethylpyridine, $\mathrm{TsOH}$, toluene, $110{ }^{\circ} \mathrm{C}, 89 \%$; (b) $\mathrm{Cu}(\mathrm{OTf})_{2}$; benzoin, $\mathrm{Et}_{3} \mathrm{~N}$, acetone; $\mathrm{O}_{2} ; \mathrm{HCl} ; \mathrm{NH}_{4} \mathrm{OH}, 25 \%$; (c) $\mathrm{Ac}_{2} \mathrm{O}$, pyridine, 97\%; (d) $\mathrm{PhN}(\mathrm{Tf})_{2}, \mathrm{KHMDS}, \mathrm{THF},-78{ }^{\circ} \mathrm{C}$ to 25 ${ }^{\circ} \mathrm{C}, 91 \%$.

Pd-catalyzed Sonogashira coupling of vinyl triflate 43 and alkyne 33 provided enyne 44 in $94 \%$ yield (Scheme 8). Sharpless dihydroxylation of the enyne proceeded with complete stereocontrol to install the $\alpha$-hydroxyl at C17. Further oxidation with benzeneseleninic anhydride ${ }^{22}$ converted the cis-diol into unstable $\alpha$-hydroxy cyclopentenone $\mathbf{4 5}$ in fairly low yield despite extensive efforts toward optimization. 
Scheme 8. Completion of the synthesis of the eastern half of cephalostatin $1^{a}$
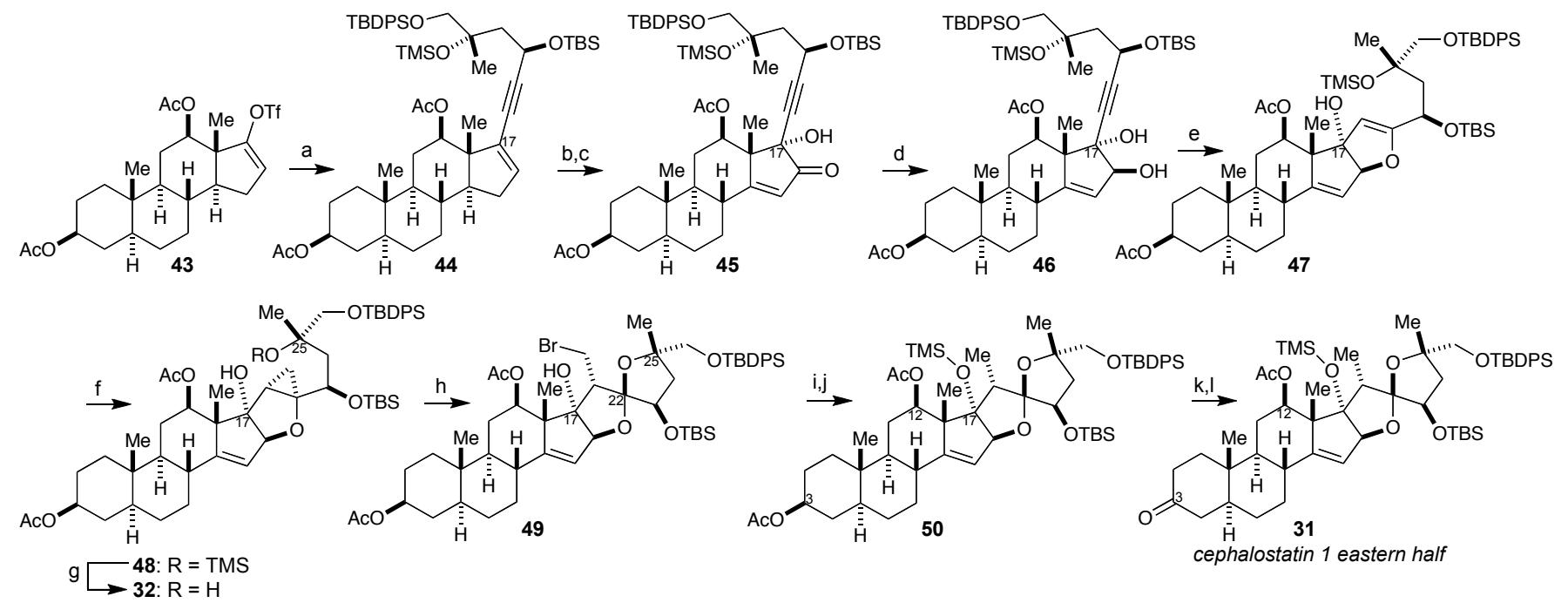

${ }^{a}$ Conditions: (a) 33, $\left(\mathrm{Ph}_{3} \mathrm{P}\right)_{4} \mathrm{Pd}$, CuI, $i \mathrm{Pr}_{2} \mathrm{EtN}$, DMF, 94\%; (b) (DHQ) ${ }_{2} \mathrm{PHAL}, \mathrm{K}_{2} \mathrm{CO}_{3}, \mathrm{~K}_{3} \mathrm{Fe}(\mathrm{CN})_{6}$, $\mathrm{MeSO}_{2} \mathrm{NH}_{2}, \mathrm{~K}_{2} \mathrm{OsO}_{4} \cdot 2 \mathrm{H}_{2} \mathrm{O}, \mathrm{tBuOH}, \mathrm{H}_{2} \mathrm{O}, 95 \%$; (c) $(\mathrm{PhSeO})_{2} \mathrm{O}, \mathrm{K}_{2} \mathrm{CO}_{3}$, toluene, $110{ }^{\circ} \mathrm{C}$; (d) $\mathrm{NaBH}(\mathrm{OAc})_{3}$, THF, $65^{\circ} \mathrm{C}, 36 \% 2$ steps; (e) $\mathrm{Ph}_{3} \mathrm{PAuCl}, \mathrm{AgBF}_{4}, \mathrm{THF}, 88 \%$; (f) $\mathrm{CH}_{2} \mathrm{I}_{2}, \mathrm{Et}_{2} \mathrm{Zn}$, toluene, 0 ${ }^{\circ} \mathrm{C}$; (g) PPTS, $\mathrm{CH}_{2} \mathrm{Cl}_{2}, \mathrm{MeOH}, 73 \% 2$ steps; (h) NBS, THF, $-10{ }^{\circ} \mathrm{C}$; (i) $\mathrm{Bu}_{3} \mathrm{SnH}$, AIBN, toluene, $110{ }^{\circ} \mathrm{C}$; (j) TMSOTf, pyridine, $65 \% 3$ steps; (k) $\mathrm{KHCO}_{3}, \mathrm{MeOH}, \mathrm{H}_{2} \mathrm{O}, 65{ }^{\circ} \mathrm{C}$; (l) $\mathrm{HCrO}_{4}, \mathrm{Et}_{2} \mathrm{O}, \mathrm{CH}_{2} \mathrm{Cl}_{2}, 0{ }^{\circ} \mathrm{C}$, $88 \% 2$ steps.

Treatment of the enone 45 with $\mathrm{NaBH}(\mathrm{OAc})_{3}$ resulted in $\mathrm{C} 17$ hydroxyl-directed reduction to transdiol 46. Diol 46 underwent $\mathrm{Au}(\mathrm{I})$-catalyzed 5-endo-dig cyclization ${ }^{23}$ to provide dihydrofuran 47 in $88 \%$ yield. It is worth noting the ease with which the $\mathrm{Au}(\mathrm{I})$-catalyzed cyclization takes place on what is a highly hindered internal alkyne. Again using the C17 hydroxyl as a directing group, Simmons-Smith conditions stereoselectively converted the dihydrofuran $\mathbf{4 7}$ to cyclopropane $\mathbf{4 8}$ with an $\alpha$ configuration. Deprotection of the C25 hydroxyl with PPTS delivered spiroketalization substrate $\mathbf{3 2}$ as a single diastereomer in $73 \%$ yield from 47 . Treatment of 32 with Zeise's dimer $\left[\left\{\left(\eta^{2}-\mathrm{C}_{2} \mathrm{H}_{4}\right) \mathrm{PtCl}\right\}_{2}\right]$, resulted in quantitative spiroketalization; ${ }^{24}$ however, the undesired C22- $(R)$ spiroketal stereoisomer was favored by a 13:1 ratio. This may be due to $\mathrm{HCl}$ generated during the reaction and attempts to buffer the reaction with nitrogenous bases inhibited spiroketalization. We later discovered that oxidative spiroketalization using NBS in THF furnished a separable mixture of bromomethylene spiroketals favoring the desired C22- $(S)$ isomer 49 by a 5:1 ratio. Lack of equilibration in this reaction is due to the neutral reaction 
conditions. Debromination of 49 by $\mathrm{Bu}_{3} \mathrm{SnH} / \mathrm{AIBN}$ followed by silylation of the extremely hindered C17 hydroxyl using neat pyridine/TMSOTf delivered $\mathbf{5 0}$ in $65 \%$ yield from 49 . Selective hydrolysis of the $\mathrm{C} 3$ acetate (the $\mathrm{C} 12$ acetate is shielded by the C17 OTMS group) followed by Brown-modified Jones oxidation $^{25}$ provided 31, the eastern half of cephalostatin 1, in $88 \%$ yield over two steps.

\section{Completion of a synthesis of cephalostatin 1.}

To prepare the A rings of western half $\mathbf{5}$ and eastern half $\mathbf{3 1}$ for pyrazine coupling, we used a sequence of reactions developed by Fuchs ${ }^{11 \mathrm{~b}}$ (Scheme 9). Bromination $\alpha$ to the $\mathrm{C} 3$ ketone and azidation with tetramethylguanidinium azide in $\mathrm{EtNO}_{2}$ provided $\mathbf{5 2}$ from $\mathbf{5}$ and $\mathbf{5 4}$ from $\mathbf{3 1}$. The C3 ketone of $\mathbf{5 4}$ was converted to methoxime 55, and Staudinger reduction of the azide to an amine gave pyrazine coupling partner 56. 52 and $\mathbf{5 6}$ were treated with polyvinylpyridine and $\mathrm{Bu}_{2} \mathrm{SnCl}_{2}$ in refluxing benzene to provide protected cephalostatin $1(\mathbf{5 7})$ along with a trace of recovered 56. Global deprotection of the silyl groups and the $\mathrm{C} 12$ acetate was affected by TBAF in refluxing THF to afford cephalostatin 1 in 47\% yield from $\mathbf{5 2}$.

Scheme 9. Pyrazine coupling and completion of the synthesis of cephalostatin $1^{a}$ 


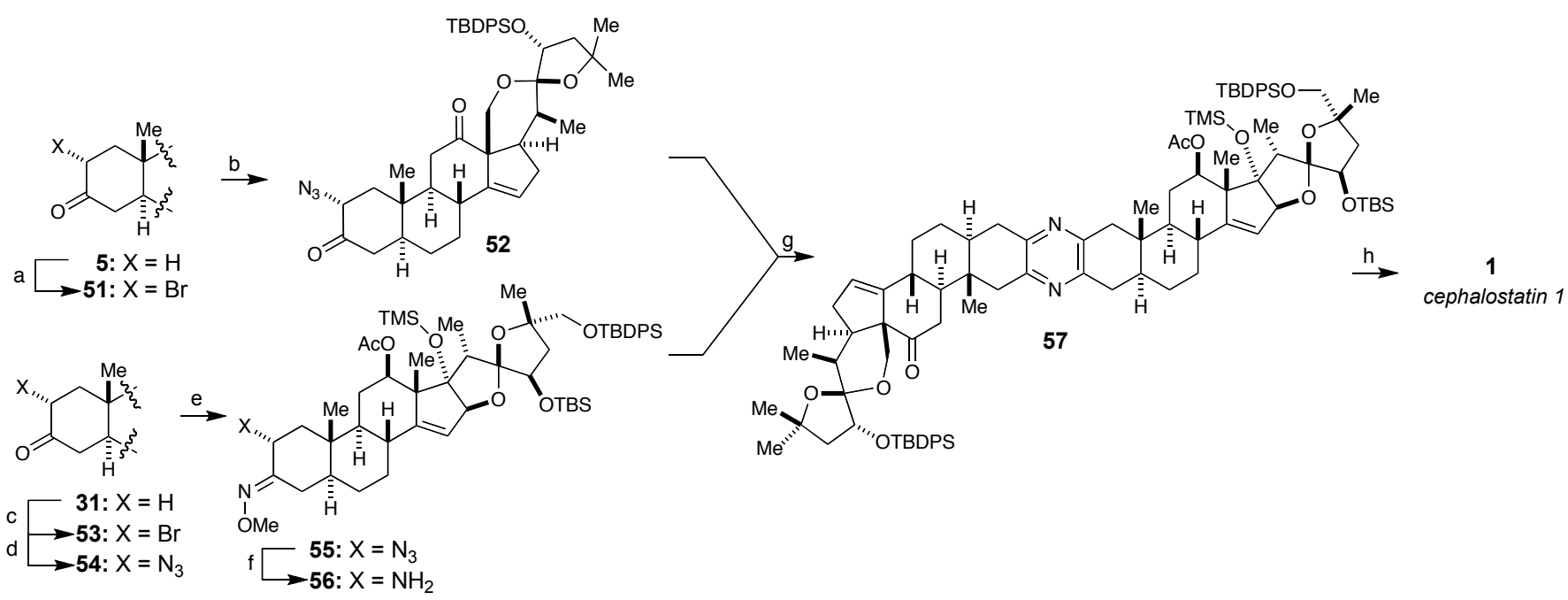

${ }^{a}$ Conditions: (a) $\mathrm{PhMe}_{3} \mathrm{NBr}_{3}$, THF, $0{ }^{\circ} \mathrm{C}$; (b) tetramethylguanidinium azide, $\mathrm{EtNO}_{2}, 83 \% 2$ steps; (c) $\mathrm{PhMe}_{3} \mathrm{NBr}_{3}$, THF, $0{ }^{\circ} \mathrm{C}$; (d) tetramethylguanidinium azide, $\mathrm{EtNO}_{2}, 78 \% 2$ steps; (e) $\mathrm{NH}_{2} \mathrm{OMe} \bullet \mathrm{HCl}$, pyridine $/ \mathrm{CH}_{2} \mathrm{Cl}_{2}$; (f) $\mathrm{PPh}_{3}, \mathrm{THF} / \mathrm{H}_{2} \mathrm{O}, 0$ to $25^{\circ} \mathrm{C}, 77 \% 2$ steps; (g) polyvinylpyridine, $\mathrm{Bu}_{2} \mathrm{SnCl}_{2}$, benzene, $80{ }^{\circ} \mathrm{C}$; (h) TBAF, THF, $47 \% 2$ steps.

In conclusion, an enantioselective synthesis of cephalostatin 1 has been achieved. In the course of our synthesis of the western half, a unique methyl group-selective allylic oxidation was developed. PTAD underwent selective functionalization of the C18 methyl group, apparently directed by a proximal aldehyde. Subsequent [2,3]-sigmatropic rearrangement and oxidative hydrolysis of the resulting urazole led to a $\mathrm{C} 18$ aldehyde that could not be produced using other methods. This allylic functionalization sequence may be useful in other systems where conventional methods fail. Key steps in the eastern half synthesis include a remote $\mathrm{C}-\mathrm{H}$ hydroxylation of $\mathrm{C} 12$, Sonogashira coupling between a steroid-derived vinyl triflate and an alkyne containing most of the atoms of the $\mathrm{E}$ and $\mathrm{F}$ rings, a $\mathrm{Au}(\mathrm{I})$-catalyzed 5-endodig cyclization, and a kinetic spiroketalization by cyclopropane ring opening. Our goal is to uncover the cellular target of cephalostatin 1 and explore its therapeutic potential. This synthesis is a first step toward achieving these goals.

Acknowledgment. We thank Novartis and Taiho Pharmaceutical Co., Ltd. for providing financial support for this project.

Supporting Information Available: Experimental procedures and spectral data for new compounds. This material is available free of charge via the Internet at http://pubs.acs.org. 


\section{References}

${ }^{\dagger}$ Harvard University.

${ }^{\ddagger}$ Gilead Sciences, Inc., Foster City, CA.

$\S$ Taiho Pharmaceutical Co., Ltd., Saitama, Japan.

(1) Kaelin, W. G., Jr. Nat. Rev. Cancer 2005, 5, 689-698.

(2) Serrano, M. Exp. Cell Res. 1997, 237, 7-13.

(3) Kubo, A.; Nakagawa, K.; Varma, R. K.; Conrad, N. K.; Cheng, J. Q.; Lee, W. C.; Testa, J. R.; Johnson, B. E.; Kaye, F. J.; Kelley, M. J. Clin. Cancer Res. 1999, 5, 4279-4286.

(4) Pettit, G. R.; Inoue, M.; Kamano, Y.; Herald, D. L.; Arm, C.; Dufresne, C.; Christie, N. D.; Schmidt, J. M.; Doubek, D. L.; Krupa, T. S. J. Am. Chem. Soc. 1988, 110, 2006-2007.

(5) NCI-60 data are available on the web at http://dtp.nci.nih.gov. Cephalostatin 1 is NSC-363979.

(6) Fukuzawa, S.; Matsunaga, S.; Fusetani, N. J. Org. Chem. 1995, 60, 608-614.

(7) (a) Kubo, S.; Mimaki, Y.; Terao, M.; Sashida, Y.; Nikaido, T.; Ohmoto, T. Phytochemistry 1992, 31, 3969-3973. (b) Mimaki, Y.; Kuroda, M.; Kameyama, A.; Sashida, Y.; Hirano, T.; Oka, K.; Maekawa, R.; Wada, T.; Sugita, K.; Beutler, J. A. Bioorg. Med. Chem. Lett. 1997, 7, 633-636.

(8) Beutler, J. A.; Shoemaker, R. H.; Johnson, T.; Boyd, M. R. J. Nat. Prod. 1998, 61, 1509-1512.

(9) Zhou, Y.; Garcia-Prieto, C.; Carney, D. A.; Xu, R. H.; Pelicano, H.; Kang, Y.; Yu, W.; Lou, C.; Kondo, S.; Liu, J.; Harris, D. M.; Estrov, Z.; Keating, M. J.; Jin, Z.; Huang, P. J. Natl. Cancer Inst. $\mathbf{2 0 0 5}, 97,1781-1785$. 
(10) (a) Dirsch, V. M.; Muller, I. M.; Eichhorst, S. T.; Pettit, G. R.; Kamano, Y.; Inoue, M.; Xu, J. P.; Ichihara, Y.; Wanner, G.; Vollmar, A. M. Cancer Res. 2003, 63, 8869-8876. (b) Muller, I. M.; Dirsch, V. M.; Rudy, A.; Lopez-Anton, N.; Pettit, G. R.; Vollmar, A. M.; Mol. Pharmacol. 2005, 67, 16841689. (c) Lopez-Anton, N.; Rudy, A.; Barth, N.; Schmitz, M. L.; Pettit, G. R.; Schulze-Osthoff, K.; Dirsch, V. M.; Vollmar, A. M. J. Biol. Chem. 2006, 281, 33078-33086.

(11) (a) Jeong, J. U.; Sutton, S. C.; Kim, S.; Fuchs, P. L. J. Am. Chem. Soc. 1995, 117, 10157-10158. (b) LaCour, T. G.; Guo, C.; Bhandaru, S.; Fuchs, P. L.; Boyd, M. R. J. Am. Chem. Soc. 1998, 120, 692707. (c) Jeong, J. U.; Guo, C.; Fuchs, P. L. J. Am. Chem. Soc. 1999, 121, 2071-2084. (d) Kim, S.; Sutton, S. C.; Guo, C.; LaCour, T. G.; Fuchs, P. L. J. Am. Chem. Soc. 1999, 121, 2056-2070. (e) Lee, S.; Fuchs, P. L. Org. Lett. 2002, 4, 317-318.

(12) (a) Smith, S. C.; Heathcock, C. H. J. Org. Chem. 1992, 57, 6379-6380. (b) Smith, S. C.; Heathcock, C. H. J. Org. Chem. 1994, 59, 6828-6839.

(13) Guo, C.; Bhandaru, S.; Fuchs, P. L. J. Am. Chem. Soc. 1996, 118, 10672-10673.

(14) Bhandaru, S.; Fuchs, P. L. Tetrahedron Lett. 1995, 36, 8351-8354.

(15) $\$ 5.50 / \mathrm{g}$ from Natland International Corporation.

(16) Bladon, P.; McMeekin, W.; Williams, I. A. J. Chem. Soc. 1963, 5727-5737.

(17) Lee, J. S.; Fuchs, P. L. Org. Lett. 2003, 5, 3619-3622.

(18) (a) Corey, E. J.; Guzman-Perez, A.; Noe, M. C. J. Am. Chem. Soc. 1995, 117, 10805-10816. (b) Chen, C.; Sparks, S. M.; Martin, S. F. J. Am. Chem. Soc. 2006, 128, 13696-13697.

(19) Frantz, D. E.; Fässler, R.; Carreira, E. M. J. Am. Chem. Soc. 2000, 122, 1806-1807.

(20) Smith, A. B.; Razler, T. M.; Pettit, G. R.; Chapuis, J. Org. Lett. 2005, 7, 4403-4406. 
(21) Schönecker, B.; Lange, C.; Zheldakova, T.; Günther, W.; Görls, H.; Vaughan, G. Tetrahedron $\mathbf{2 0 0 5}, 61,103-114$.

(22) Kutney, J. P.; Piotrowska, K.; Somerville, J.; Huang, S.; Rettig, S. J. Can. J. Chem. 1989, 67, $580-589$.

(23) Belting, V.; Krause, N. Org. Lett. 2006, 8, 4489-4492.

(24) Beyer, J.; Madsen, R. J. Am. Chem. Soc. 1998, 120, 12137-12138.

(25) Brown, H. C.; Garg, C. P.; Liu, K. T. J. Org. Chem. 1971, 36, 387-390.

TOC Graphic:

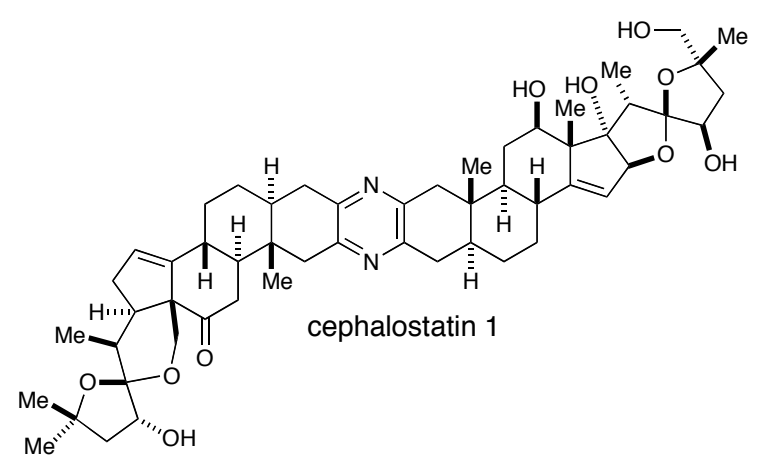

